\title{
Congenital elbow luxation grade I treated by radial head ostectomy in an English Bulldog*
}

\section{Luxação congênita de cotovelo grau I tratada por ostectomia da cabeça do rádio em um Bulldog Inglês}

\author{
Daniel Cardoso Garcia, ${ }^{* *, * * *}$ Larissa Eckmann Mingrone Garcia, ${ }^{* *}$ Rosane Melo, ${ }^{* *}$ Marcelo Jorge Cavalcanti de Sá ${ }^{* * *}$
}

\begin{abstract}
Resumo
O objetivo deste relato foi o de apresentar o acompanhamento tardio de um caso de luxação congênita de cabeça de rádio (LCCR) em um Buldog Inglês jovem, tratada por ostectomia da cabeça radial (OCR). A LCCR é uma condição incomum nos cães, mas é a forma mais comum de luxação de cotovelo nos mesmos (grau I). Um Bulldog Inglês, macho, 6 meses, 14 quilos, foi atendido com suspeita de luxação do cotovelo. Exame físico revelou uma proeminência na superfície lateral do cotovelo direito, além de claudicação grau I e dor leve. Amplitude de movimento apresentava-se normal. Radiografias e tomografia prévias confirmaram LCCR. Optou-se pela OCR ao invés de técnicas corretivas, devido à idade do animal à época do procedimento e à dificuldade no reposicionamento do rádio na articulação. Após 3 anos e meio de pós-operatório, foram realizados novos exames clínicos e radiográficos. O paciente não apresentava dor, apresentava bom apoio do membro e boa amplitude de movimento, permitindo bom movimento do cotovelo. Houve um novo crescimento parcial do segmento proximal da cabeça do rádio ocasionando melhor readequamento do mesmo na articulação. Sinais leves de degeneração articular estavam presentes. A OCR se mostrou efetiva neste caso, provando ser uma boa técnica a ser utilizada nos casos de LCCR quando tratamento conservativo ou técnicas de redução já não podem ser mais utilizados.
\end{abstract}

Palavras-chave: Cães, Deslocamento rádio-umeral, Imagem, Acompanhamento tardio.

\begin{abstract}
The aim of this study is to report a long term follow up of a congenital luxation of the radial head (CLRH) case of a young Bulldog treated by radio head ostectomy (RHO). CLRH is an uncommon condition in dogs, but it is the most commom form of elbow dislocation (grade I). An English Bulldog, male, 6 months, 14 kilograms, was suspected of elbow dislocation. Physical examination revealed a lateral proeminence on the lateral surface of the right elbow, as well as grade I lameness and mild pain. Range of motion was normal. Previous radiographs and tomography confirmed CLHR. RHO was chosen instead of corrective techniques, due to the age of the animal at the time of the procedure and the difficulty in repositioning the radial head in the joint. Three and a half years after surgery, new clinical and radiographic examaminations were performed. The patient had no pain, good limb support and good range of motion, allowing good elbow movement. There was a partial regrowth of the proximal segment of the radial head causing better readjustment of it in the joint. Mild signs of joint degeneration were present. RHO proved to be effective in this case, proving to be a good technique to be used in cases of CLRH when conservative treatment or reduction techniques can no longer be used.
\end{abstract}

Keywords: Born, Dogs, Image, Long term follow-up, Radio-humeral dislocation.

\section{Introduction}

Congenital luxation of the radial head (CLRH) is an uncommon condition of the canine elbow (Dassler and Vasseur, 2003; Piermattei et al., 2006; Clark et al., 2010). It is the most common form of congenital elbow luxation in the dog (CEL grade I). There is no sex or breed predisposition (Kene et al., 1982; Dassler and Vasseur, 2003), eventough, male dogs seem to be overrepresented (CooK, 2001). Medium and large size breeds are the most commonly affected. CLRH is commonly noticed around 3 months of age (Campbell, 1969; Spadari et al., 2001;
Dassler and Vasseur, 2003; Piermattei et al., 2006; Heindenreich et al., 2015).

There has been very little research to document a consistent anatomical defect leading to CLRH (Campbell, 1969; Gurevitch and Hohn, 1980; Heindenreich et al., 2015). Some hypothesis suggests failure of proper formation of the colateral ligaments, agenesis or hypoplasia of the annular ligament, and hypoplasia or aplasia of the radius or ulnar coronoid process. (Bingel and Riser, 1977; Gurevitch and Hohn, 1980; Spadari et al., 2001; Valastro et al., 2005).

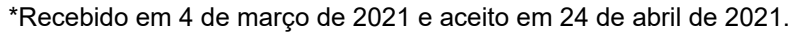

${ }^{* *}$ Animal Care Barueri Clínica Veterinária, Barueri, SP, Brazil.

***Universidade Federal de Campina Grande (UFCG), Patos, PB, Brazil.

@Correspondence to: Daniel C. Garcia (Animal Care Barueri), Rua Duque de Caxias, n 226, Centro, Barueri, SP, Brazil. Zip code: $06401-010$.

Email: danielcardosogarcia@gmail.com. Phone number: (55) (11) 99618-3304.
} 
Clinical signs include a mild forelimb lameness, which is first noticed around 3 months of age, mild pain or discomfort (Milton and Montgomery, 1987), and reduced range of motion in flexion and extension of the elbow (Clark et al., 2010).

Radiographically, the luxated radial head is usually seen lateral and caudal to the articular surface of the humerus on craniocaudal and mediolateral views, respectively (Griffon, 2011). The radial epiphysis is often convex, as it has never articulated with the humerus. (Clark et al., 2010).

Many surgical techniques have been described for correction of luxation of the radial head, however there is limited literature specifically concerning the congenital form. In addition, many of the reported cases have short follow-up periods (Campbell, 1969; Spadari et al., 2001; McDonell, 2004; Fafard, 2006; Clark et al., 2010). When surgery is done after the age of $4-5$ months, acute correction may not be effective since it is very difficult positioning the radial head in the joint in a properly manner and other surgical techniques can be indicated, such as radial head ostectomy (RHO) (Heindenreich et al., 2015). But RHO has been reported by Dassler and Vasseur (2003) to have a poor outcome.

The aim of this study is to report a clinical and radiograph long term follow up of a CLRH case in a young Bulldog treated by $\mathrm{RHO}$.

\section{Case Report}

A 6 months old, male English Bulldog, weighting 14 kilograms, presenting grade 1 lameness degree was reported for the second time to orthopedic evaluation. Previously, when he was
2 months old, this patient was reported for the first time with a lateral prominence noted on the lateral surface of the right elbow. Angular deformity or a bow shaped arm were not visible. Pain during flexion or extension or lameness were not noticed at the first attempt, but mild pain and grade 1 lameness were noted now when he was 6 months old. There was not limited elbow range of motion in neither of the clinical visits. There were not other concurrent diseases.

At first, for a correct diagnosis, radiographs were taken from both right and left elbows (Figure 1). CEL grade I was confirmed on right arm radiographies with a radial head luxation in a caudolateral manner in respect to the ulna. The radial and ulnar distal growth plates were normal in both thoracic limbs.

Still when he was 2 months old, a computer tomography (CT) was done to evaluate the radial head proximal extremity shape and the articular surface in a 3D reconstruction pattern with the intent to do a better surgical planning for an acute surgical correction with plate, screws and pins, instead of ostectomy (Figure 2). But, even with a CLRH diagnosis, the client denied surgery and preferred a conservative treatment, doing rest and controlled exercises. But, four months later, when he was 6 months old, the patient came back with mild pain and grade 1 lameness. Antiinflamatory and pain medications were prescribed and new radiographies were carried out (Figure 3 ). The radial head was still luxated caudolaterally in respect to the ulna and the radial and ulnar distal physis were normal. At this time acute reduction were not a possibility due to the impossibility in repositioning the radial head in the joint, and a radial head ostectomy was performed.

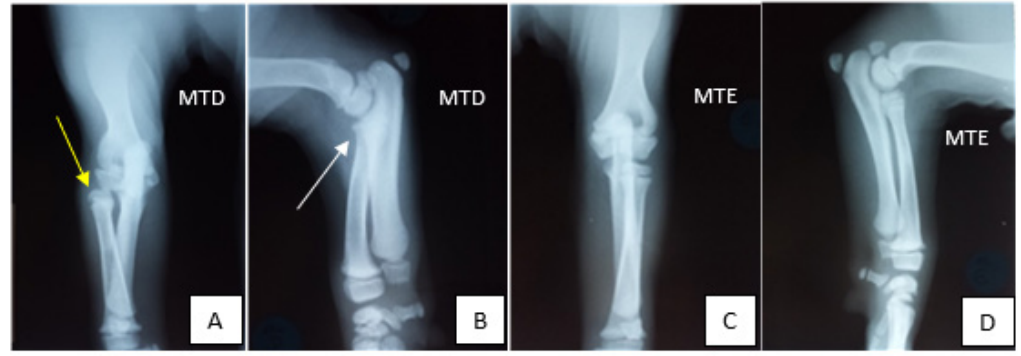

Figure 1: Mediolateral and craniocaudal views of the abnormal right elbow $(A, B)$ and normal left elbow $(C, D)$. Note the lateral luxation of the radial head in $A$ (yellow arrow) and its caudal luxation and sobreposition with the proximal ulna in B (white arrow). MTD $=$ Right thoracic limb. MTE $=$ Left thoracic limb
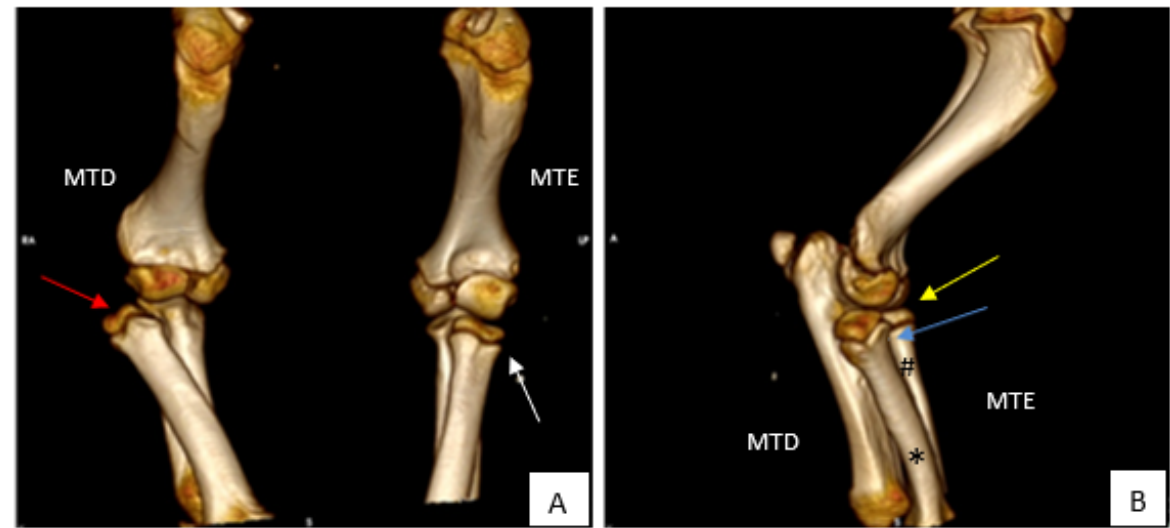

Figure 2: $3 \mathrm{D}$ reconstruction computer tomography showing both right and left elbows. Cranial and lateral views ( $A$ and $B$, respectively). In $A$, note the lateral luxation of the right radial head (red arrow) compared with the left side (white arrow). In B, note the caudal luxation of the right radial head (blue arrow) compared with the left side (yellow arrow). MTD = Right thoracic limb. MTE $=$ Left thoracic limb. $*$ MTD in B and \# = MTE in B 


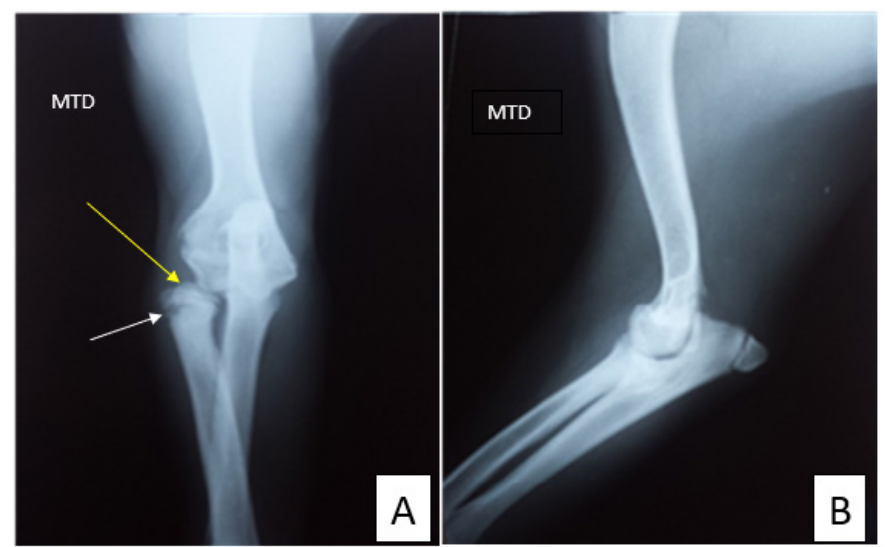

Figure 3: Now, patient with 6 months old. Craniocaudal (A) and mediolateral (B) views of the abnormal right elbow after conservative treatment. Even after 4 months, there is still a visible latero-caudal luxation of the radial head in respect to the humerus condyle and ulna (yellow arrow). The proximal radial growth plate which is seen in A is still open on the lateral side (white arrow), but is closed on the medial side due to constant trauma with the lateral humerus condyle.

\section{Surgical Procedure}

The surgical procedure of RHO was done for this patient. First, morphine (Dimorf® - Cristália Prod. Quím. Farm. Ltda. Itapira - São Paulo - Brazil) in a dose of $0,5 \mathrm{mg} / \mathrm{kg}$ was done intramuscularly. After 15 minutes, anesthetic induction was made with Propofol in a dose of $5 \mathrm{mg} / \mathrm{kg}$, Diazepan (Compaz®) - Cristália Prod. Quím. Farm. Ltda. - Itapira - São Paulo - Brazil) in a dose of $0,5 \mathrm{mg} / \mathrm{kg}$ and Ketamine (Dopalen ${ }^{\circ}$ - Ceva Santé Animale - Paulínia - São Paulo - Brazil) in a dose of $1 \mathrm{mg} /$ $\mathrm{kg}$ intravenously. The animal was intubated and anesthetic mantainance was done with Isofluorane (Isoforine ${ }^{\circledR}$ - Cristália Prod. Quím. Farm. Ltda. - Itapira - São Paulo - Brazil) in a semi-closed circuit.

The patient was placed in a left lateral position with the right elbow positioned upward. The limb was shaved from the carpal joint up to the shoulder. After that, an antiseptic clorexidine solution (Riohex® - Indústria Farmacêutica Rioquímica Ltda. - São José do Rio Preto - São Paulo - Brazil) was used to prepare the limb for surgery. The distal part of the limb was covered with a sterilized plastic sack and then drapped with an elastic strip (3M Vetrap $®$ - 3M Brazil Ltda. - São Paulo - Brazil).

Surgical technique is shown in figure 4. A lateral skin incision was performed on the elbow just above the visible buttress created by the luxated radius head. Subcutaneous tissue was dissected and the extensors muscles were separeted in a way we could see the joint capsule. Gelpi retractors were used to keep the field exposed and give us good visualization. After opening the joint capsule and identify the head of the radius, all the tissue surrounding was removed with a periosteal elevator and metzembaum scisors. When we had this proximal part of the radius free from connective tissue, an ostectomy was performed about $3 \mathrm{~cm}$ below its proximal articular surface. This last procedure was done with a curved bone rongeur, and little fragments of the proximal radius were taken out until we had a complete ostectomy of its head. Extreme care was taken not to cause periostial lesion on the ulna just below the medial cortex of the radius. There were no intraoperative complications. Good lavage was made inside the elbow joint to make sure there were no debris or bone fragments in place. Joint capsule and subcutaneous tissue were sutured with 2.0 Poglicolyc Acid sutures (Ácido Poliglicólico® - Bioline fios cirúrgicos Ltda. Anápolis - Goiás - Brazil) in a separeted and continuous pattern, respectively, and skin was closed with 3.0 nylon (Nylon® - Bioline fios cirúrgicos Ltda. - Anápolis - Goiás - Brazil) in a separeted pattern.

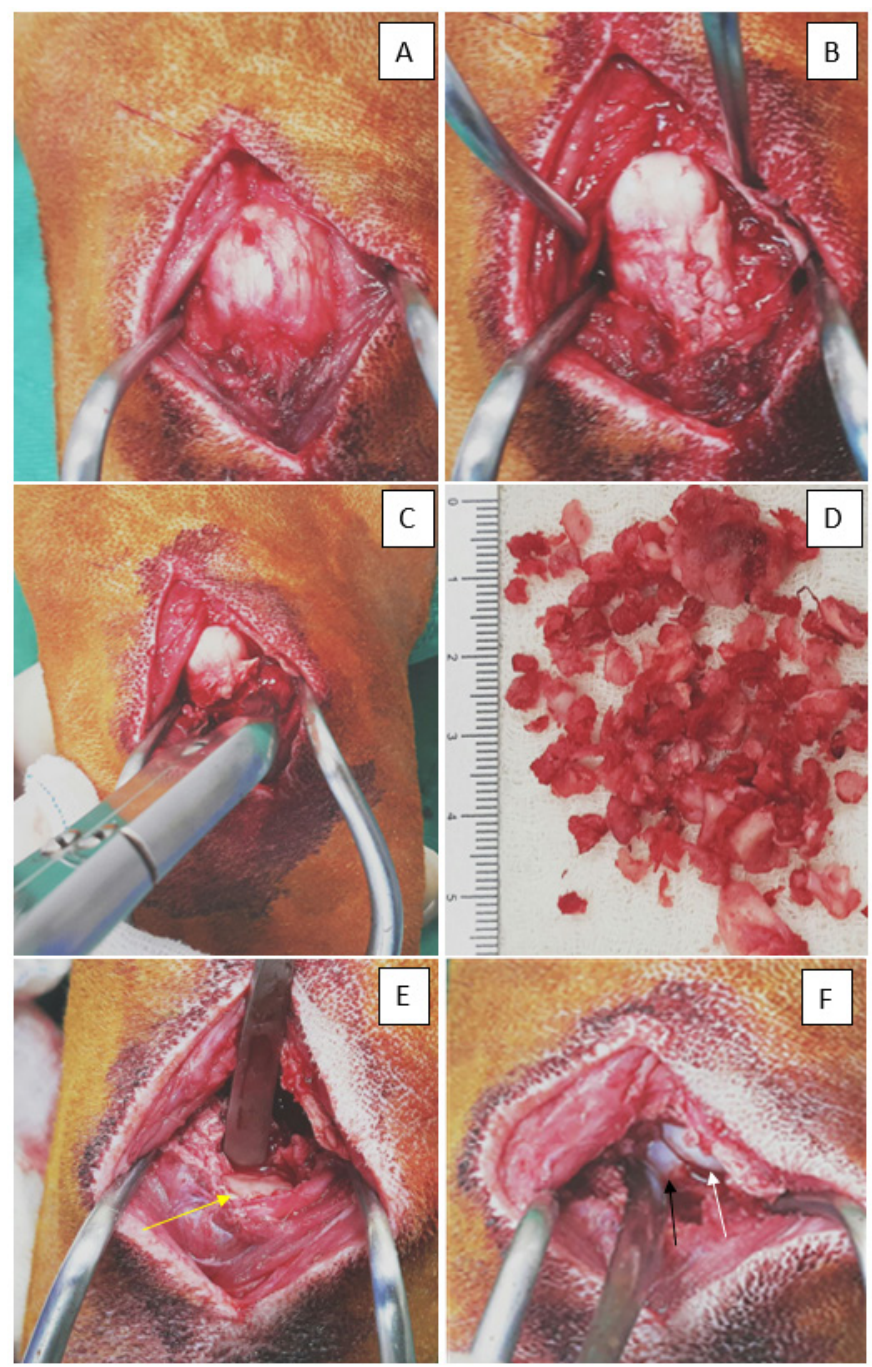

Figure 04: Lateral skin incision is made just above the abnormal lateral elbow proeminence $(A)$. Then divulsion of soft tissues surrounding the radial head is done and joint capsule incision is made (B). A bone rongeur is used to do the proximal radial ostectomy and remove the luxated radial head (C). Fragments of the radial head and proximal radius are removed from the surgery site with the use of bone rongeur (D). After radial head ostectomy the radial shaft can be seen (yellow arrow) (E). The lateral condyle of the humerus (white arrow) and the trochlear notch of the ulna (black arrow) can be identified ( $F$ ). 
A Robert Jones bandage was kept for three days. The patients were discharged the next day. Cephalexin $(22 \mathrm{mg} / \mathrm{kg})$ twice a day for 10 days, Meloxicam $(0,1 \mathrm{mg} / \mathrm{kg})$ once a day for 7 days and Tramadol ( $3 \mathrm{mg} / \mathrm{kg}$ ) twice a day for five days were prescribed. After three days, Robert Jones bandage was removed, and the animal was free to walk and move his elbow naturally. After 2 weeks, skin suture was removed, and we could test elbow range of motion and see how the animal was walking and bearing weight.

\section{Results}

No postoperatory complications were noted or mentioned by the owner. The same day of surgery, patient was already trying to bear weight on the operated thoracic limb. After 15 days, he was already capable of bearing weight normally. A follow up radiograph was taken one month later to visualize the ostectomy site (Figure 5). The ostectomy was fine, good shape and no complications as were expected. Later, a 3,5 years follow up (FU) was done after ostectomy. Clinically, the patient has improved a lot, showing no lameness or pain, and was bearing weight on the thoracic limb operated very well. He also could run without limp. No valgus deviation of hand was noted after this period. Range of motion was considered normal. At this time, follow up images have been taken (figure 6). There were signs of augmented articular interface of the elbow, proximal radius bone remodelling, partial radial head regrowth, presence of periarticular osteophytes, and bone scleroses in the level of the semilunar notch. There were no radiographic alterations of the left normal elbow joint at this period.

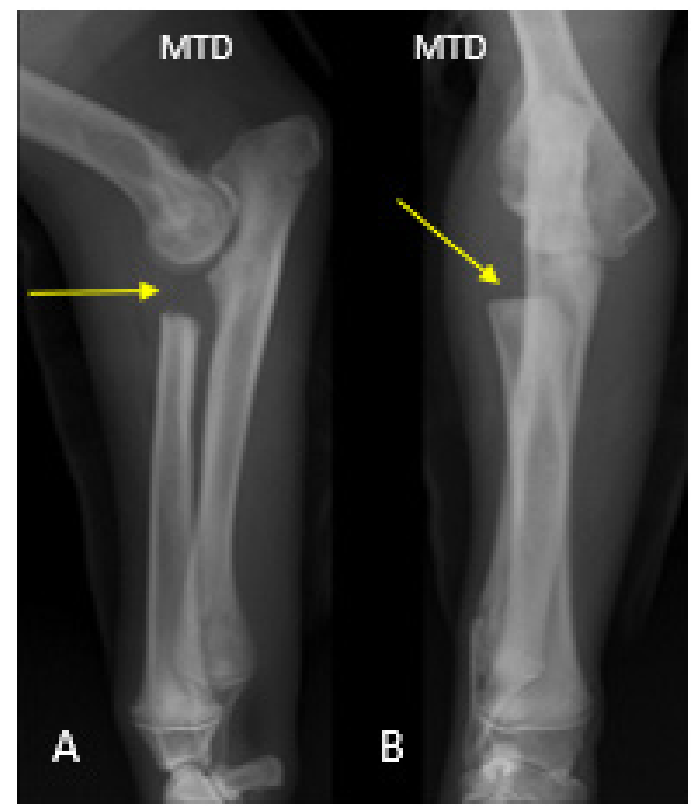

Figure 5: 1 month post operatory follow up image. Mediolateral $(A)$ and craniocaudal $(B)$ views. The ostectomy site can bee seen as a radiotransparent image above the most proximal portion of the radius ( $A$ and $B-$ yellow arrow) and below the humerus condyle. MTD = Right thoracic limb.
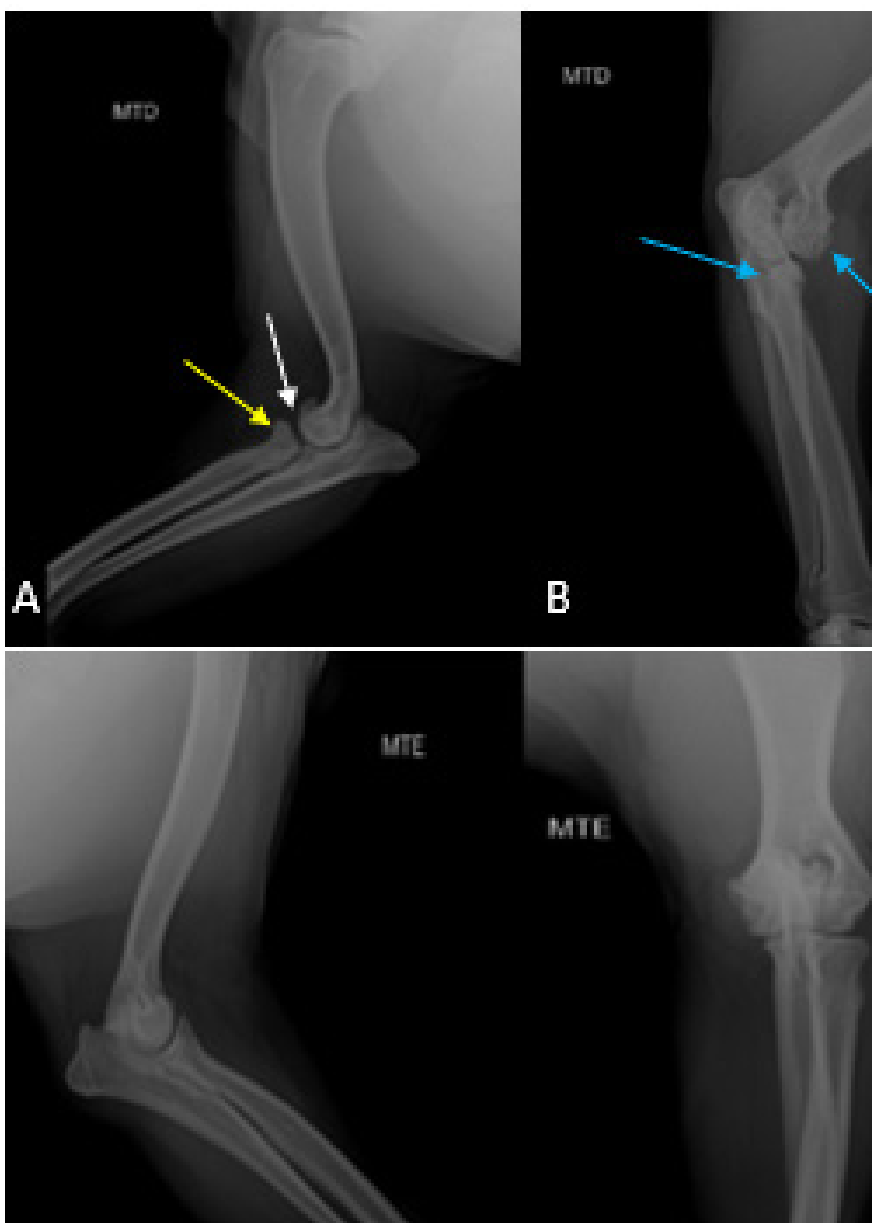

Figure 6: 3,5 years follow up images. Mediolateral and craniocaudal views of the operated right elbow (A and B). In A we can see that there is a proximal radial head regrowth/remodeling (yellow arrow), showing some similarity to a normal radial head. Also in A, it seems it is feeting the right anatomic place of the radial head, but there is an augmented articular space (white arrows) between radius and humerus. In B, there are some osteophytes and mild signs of osteoarthritis (blue arrows). Mediaolateral and craniocaudal views of the normal left elbow $(C$ and $D)$. MTD = Right thoracic limb. MTE = Left thoracic limb.

\section{Discussion}

Diferenciate CEL grade I from developmental elbow luxations is always difficult because their clinical and radiographic similarity, and specially when there is a delay in the time of recognition of clinical signs (Milton and Montgomery, 1979; Gurevitch and Hohn, 1980; Fox et al., 1983; Langley-Hobbs and Carmichael, 1996; Piermattei et al., 2006). We could follow a patient since he was 2 months of age and we can infer that their condition are compatible with CEL grade I since he was too young and there was no history of trauma. He was a male English Bulldog, we cannot infer as Cook (2001) and Dassler and Vasseur (2003) if there is or there is not a sex predisposition because it is a single case, but it corroborates with others that it is one of the most commonly affected breeds, as reported by Heindenreich et al. (2005). 
Radiographies were taken very early and there was no physis abnormalities such as early closure, or articular cartilage thickening. The luxated radial head was lying lateral and caudal to the articular surface of the humerus on craniocaudal and mediolateral views, respectively. In this case probably there was never an articulatin radius, as the luxated proximal epiphysis had a convex shape, contrastating with development luxations of the radial head which often have a flattened proximal physis demonstrating previous articulation with the humeral condyle (Fox et al., 1983; Langley-Hobbs and Carmichael, 1996; Clark et al., 2001). The humero-ulnar joint had no rotations/luxations, but only augmented articular spaces, suggesting also CEL grade I, instead of other degree (Stevens and Sander, 1974; Campbell, 1979; Kene et al., 1982; Milton and Montgomery, 1987; Clark et al., 2010).

Dassler and Vasseur (2003) and Piermattei et al. (2006) reported patients with a valgus hand before surgery, but in this case this clinical sign was not observed, and this sign could be related to condrodistrophic breeds reported by them. Lameness was evident and mild only at the second visit when the patient was 6 months, but absent when first reported. Most of the young patients could have no or mild pain, as reported by the authors (Smith, 1998; Spadari et al., 2001; Temwichtr et al., 2010). Limited range of motion was not detected in this case, condition described in some patients with this kind of pathology (Milton and Montgomery, 1987; Spadari et al., 2001).

In CEL grade I cases, treatment based on aggressive early corrective surgery as a first attempt to reduce luxation is required to potentiate success and minimize DAD while patients are still less than 4 months old (Cook et al., 2001; Dassler and Vasseur, 2003; Piermattei at al., 2006; Fafard, 2006), but in this case, it was denied by the owner at first, been necessary to do a posterior $\mathrm{RHO}$ to solve the problem. When still very young, as less then 4 months old, the radius still could be positioned surgically in a better place inside the elbow joint and remodel while there was still a potential growing up period to follow (Piermattei et al., 2006), as reported before with the use of other techniques such as modified Bell-Tawse procedure, radial head transfer, external fixators or transarticular pins (Rahal et al., 2000; Spadari et al., 2001; Fafard, 2006; Fitzpatrick, 2008). But, by owner decision, inicially we have chosen for a conservative treatment as described by Smith (1998) and Fafard, (2006), and only tried surgery if clinical signs did not improve or got worse. After a few months conservative treatment proved to be unsuccessful as mentioned by Cook et al. (2001) and surgery was recommended. But now, instead of trying correction of the humero-radial articulation, we preferred to do a $\mathrm{RHO}$ in this case.

Even being reported by some authors, there is limited bibliography concerning CEL grade I, and most of them describing few operated cases with short follow up period related to acute corrections and possibility of remodelling. To the authors knowledge, even being $\mathrm{RHO}$ reported in literature, there is only one published paper about it, at least recently, and about one case report only with 11 months of follow up (Heindenreich et al., 2015). By the time of this surgery, articular correction would be difficult due to the absence of mobility of the radius inside the elbow joint. Even being $\mathrm{RHO}$ a technique with a possible bad outcome to treat CLRH as described by Dassler and Vasseur (2003), we share the same idea as Heindenreich et al. (2015), and we thought that RHO would be the first choice for this case. Advantages related by Heindenreich et al. (2015) and shared by us to the use of this technique is that it is an easy procedure, has a lower procedure time and low cost, has a fast post operatory care, and, in non-reducible and chronic cases, we think this procedure could be considered as a first alternative instead of elbow arthodesis or even amputation if possible. However, we used a different technique than the one described by Heindenreich et al. (2015), doing only the RHO instead of using RHO plus implants, and we think this is also an advantage feature. Even being the laxity of the annular ligament and collateral ligament the possible responsible causes for the CLRH (Gurevitch and Hohn, 1980), we did not insert screws to address radial fixation to the ulna to make a surgical synostosis as described by the authors, as it could lead to an antebrachial deformity, a complication related to this procedure with the use of implants (Langley-Hobbs and Carmichael, 1996; Clark et al., 2001; Dassler and Vasseur, 2003). We did not feel a radius instability after ostectomy, so we did not think that anchors and cerclage wire used as additional joint stabilisation (Heidenreich et al., 2015) were necessary.

After 3,5 years of surgery, we could also see that the proximal radius had grown back again and partially remodeled, assuming almost a normal pattern. This situation shows that even after an ostectomy, because patients are still young, they have a residual potential for bone growing and remodeling. And we could even infeer that the age of the patient when performing a $\mathrm{RHO}$ could influence the radial head regrowth pattern and lenght seen later on the radiographies when the patient reaches adulthood. It also shows that it is possible that the bone can remodel and grow without deviation as in acute reconstruction surgeries of CEL grade I in earlier ages using other types of techniques and implants as described by some authors (Dassler and Vasseur, 2003; Piermattei et al., 2006).

Most of all, quality of life was seen after all. The grade of pain and lameness decreased after surgery. Elbow range of motion kept normal and equal to contralateral limb and little changes proved to be irrelevant to prevent patient from improving bearing weight, walk or run. The orthopedic exam after a long time from surgery reveled good patient outcome and owner satisfaction with their pet condition.

\section{Conclusion}

RHO proved to be a successful treatment for CEL grade I for the patient presented in this case. It can be indicated to young patients above 5 months of age or when reduction or conservative treatment is no longer possible or might be used before trying any other elbow savage techniques related to radial head luxation if possible. The patient showed good outcome, not only seen in a short follow up period, but also after a longer period of $\mathrm{RHO}$, demonstrating that this technique reduced the grade of lameness and pain, improving patient's quality of life. 


\section{References}

Bingel,A.S.; Riser,W.H. Congenital elbow luxation in the dog. J small Anim Pract, v.18, p.445-456, 1977.

Campbell,J.R. Nonfracture injuries to the canine elbow. J Am Vet Med Assoc, v.155, n.5, p.735-744, 1969.

Clark,K.J.; Jerram,R.M.; Walker,A.M. Surgical management of suspected congenital luxation of the radial head in three dogs. New Zeal Vet J, v.58, n.2, p.103-109, 2010.

Cook,J.L. Forelimb lameness in the young patient. Vet Clin of North Am: Small Anim Pract, v.31, v.1, p.55-83, 2001.

Dassler,C.; Vasseur,P.B. Elbow luxation. In: Slatter D., Textbook of Small Animal Surgery (3rd ed.), vol. 2. Philadelphia: The Curtis Center; 2003, pg. 1919-1926.

Fafard,A.R. Unilateral congenital elbow luxation in a Dachshund. Can Vet J, v.47, p.909-912, 2006.

Fitzpatrick,N. Radial head transfer for congenital elbow luxation: Surgical treatment of congenital and developmental luxations of the radial head. Proceedings of the American College of Veterinary Surgery Symposium. San Diego, USA; p.23-25, 2008.

Fox,S.M.; Bloomberg,M.S.; Bright,R.M. Developmental anomalies of thecanine elbow. Journal of the American Animal Hospital Association, v.19, p.605-615, 1983.

Griffon,D.J. Surgical Diseases of the Elbow. In: Tobias,K.M.; Johnson,S.A. Veterinary Surgery Small Animal (1st Ed). St. Louis, MO: WB Saunders; 2011. pg. 730-732

Gurevitch,R.; Hohn,R.B. Surgical Management of Lateral Luxation and Subluxation of the Canine Radial Head. Vet Surg, v.9, n.2, p.49-57, 1980.

Heidenreich,D.C.; Fourie,Y.; Barreau,P. Presumptive congenital radial head sub-luxation in a shih tzu: successful management by radial head ostectomy. J Small Anim Pract, v.56, p.626-629, 2015.
Kene,R.O.C.; Lee,R.; Bennett,D. The radiological features of congenital elbow luxation/subluxation in the dog. J Small Anim Pract, v.23, p.621-630, 1982.

Langley-Hobbs,S.J.; Carmichael,S. Management of a caudolateral radial head luxation in a five-month-old Shih Tzu. Vet Comp Orthop Traumat, v.9; p.186-189, 1996.

McDonell,H.L. Unilateral congenital elbow luxation in a Cavalier King Charles Spaniel. Can Vet J, v.45, p.941-943, 2004.

Milton,J.L.; Montgomery,D. Congenital Elbow Dislocations. Vet Clin of North Am: Small Anim Pract, v.17, n.4, p.873-888, 1987.

Piermattei,D.L.; Flo,G.L.; DeCamp,C.E. Congenital luxation of radial head. In: Brinker W.O.; Piermattei D.L., Flo G.L. Handbook of small animal orthopedics and fracture repair (4th ed.) St Louis: Saunder Elsevier; 2006. pg. 336-339.

Rahal,S.C.; De Biasi,F.; Vulcano,L.C.; Neto,F.J.T. Reduction of humeroulnar congenital elbow luxation in 8 dogs by using the transarticular pin. Can Vet J, v.41, p.849-853, 2000.

Smith,G.K. Fractures and luxations of the elbow. Vet Q, v.20, p.26-29, 1998.

Spadari,A.; Romagnoli,N.; Venturini,A. A modified Bell-Tawse procedure for surgical correction of congenital elbow luxation in a Dalmatian puppy. Vet Comp Orthop Traumatol, v.14, p.210-213, 2001.

Stevens,D.R.; Sander,R.D. An elbow dysplasia syndrome in the dog. Journal of the American Veterinary Medical Association, v.165, p.1065-1069, 1974.

Temwichitr,J.; Leegwater,P.A.J.; Auriemma,E.; Van't Veld,E.M.; Zijlstra,C.; Voorhout,G.; Hazewinkel,H.A.W. Evaluation of radiographic and genetic aspects of hereditary subluxation of the radial head in Bouviers des Flandres. Ame J Vet Res, v.71, n.8, p.884-890, 2010.

Valastro,C.; Di Bello,A.; Crovace,A. Congenital elbow subluxation in a cat. Vet Radiol \& Ultras, v.46, n.1, p.63-64, 2005. 